\title{
Inhibitory effect of a cholecystokinin antagonist on the proliferative response of the pancreas to pancreatobiliary diversion
}

\author{
P Watanapa, E F Efa, K Beardshall, J Calam, C E Sarraf, M R Alison, R C N Williamson
}

\begin{abstract}
Since pancreatobiliary diversion probably stimulates pancreatic growth by increasing cholecystokinin secretion, the effect of the cholecystokinin antagonist CR-1409 on this adaptive response was tested. Male Wistar rats $(n=108$ ) weighing $220-250 \mathrm{~g}$ were randomised to receive either pancreatobiliary diversion $(n=60)$ or sham diversion $(n=48)$ and thereafter to receive either saline injections or CR-1409 (10 mg/kg/day, subcutaneously). Rats were killed at four, seven, and 14 days postoperatively, when blood was obtained for cholecystokinin assay and the pancreas was assessed for proliferative activity by three techniques: nucleic acid and protein assay, bromodeoxyuridine labelling, and metaphase arrest after vincristine administration $(1 \mathrm{mg} /$ $\mathbf{k g}$, intraperitoneally). Pancreatobiliary diversion increased plasma cholecystokinin concentrations by $91 \%$ at seven days and $137 \%$ at 14 days, irrespective of CR-1409 treatment. Total pancreatic RNA content was doubled by pancreatobiliary diversion at four days $(2 \cdot 15 v$ $1.07 \mathrm{mg} / 100 \mathrm{~g}$ body weight: $\mathrm{p}<0.001)$ and at seven days $(3.43 v 1.76 \mathrm{mg} / 100 \mathrm{~g}: \mathrm{p}<0.001)$, and trebled at 14 days $(4.27 v 1.32 \mathrm{mg} / 100 \mathrm{~g}$ : $\mathbf{p}<\mathbf{0 . 0 0 1 )}$. Pancreatobiliary diversion increased bromodeoxyuridine labelling index from $1 \cdot 1$ to $3.7 \%$ at seven days and the cell birth rate from 0.09 to $0.06 \%$. CR-1409 completely abolished this proliferative response and partly prevented the rise in RNA. The results confirm pancreatic hypertrophy and increased acinar cell proliferation after pancreatobiliary diversion. CR-1409 prevents this adaptive growth, probably by blocking cholecystokinin receptors. Bromodeoxyuridine labelling and the metaphase arrest technique may be used to assess pancreatic cell kinetics.
\end{abstract}

Departments of Surgery, Histopathology, and Medicine, Royal

Postgraduate Medical School, Hammersmith Hospital, London

$P$ Watanapa

E F Efa

K Beardshall

J Calam

C E Sarraf

M R Alison

R C N Williamson

Correspondence to:

Professor R C N Williamson,

Department of Surgery,

Hammersmith Hospital,

RPMS, Du Cane Road,

Accepted for publication

4 October 1990 papilla, the resultant pancreatic hyperplasia is associated with a considerable increase in circulating cholecystokinin'; the absence of pancreatic enzymes from the upper small bowel interrupts normal feedback inhibition of cholecystokinin release.

Pancreatic adaptation has been less intensively studied than intestinal adaptation. Organ mass can be assessed by measuring the wet weight of the pancreas plus its content of DNA, RNA, and protein. Cell proliferation is much less rapid than in the gut and correspondingly more difficult to determine. Since humoral factors should influence cell turnover before increasing organ mass, we have assessed the proliferative status of the pancreas by adopting two established techniques used elsewhere in the gut, namely the bromodeoxyuridine labelling index and metaphase arrest enumeration after vincristine. ${ }^{5}$

The availability of potent specific cholecystokinin antagonists offers an opportunity to study the particular contribution of this hormone to pancreatic adaptation after pancreatobiliary diversion. CR-1409 is a glutaramic acid derivative with a high affinity for the cholecystokinin receptor. We have used nucleic acid and protein assay, bromodeoxyuridine labelling index, and the metaphase arrest technique to show that CR1409 can inhibit the adaptive response of the rat pancreas to pancreatobiliary diversion without preventing the hypercholecystokininaemia caused by the procedure.

\section{Methods}

EXPERIMENTAL DESIGN

Male Wistar rats $(n=108)$ weighing $220-250 \mathrm{~g}$ were housed in groups of five in animal quarters with a 12 hour day/night cycle. Standard pelleted rat food (Paterson and the Christopher Hill Group, Porton-diet PRD) and water were freely available. After 72 hours of acclimatisation, animals were randomised to receive either pancreatobiliary diversion $(n=60)$ or sham pancreatobiliary diversion, comprising triple small bowel transection and resuture $(n=48)$. Pancreatobiliary diversion involved transposition of $50 \mathrm{~cm}$ jejunum to lie between the pylorus and duodenal papilla, ${ }^{+6}$ while in shams the small bowel was divided immediately distal to the pylorus, at the duodenojejunal junction and again at the level of the mid-small bowel. Operations were carried out under light ether anaesthesia. A continuous $6 / 0$ silk suture was used for intestinal anastomoses.

Immediately after the operation, half the animals in each group were further randomised to receive either CR-1409 (10 mg/kg/day) or saline $(2.5 \mathrm{ml} / \mathrm{kg})$ by daily subcutaneous injection. CR-1409 was dissolved in distilled water 


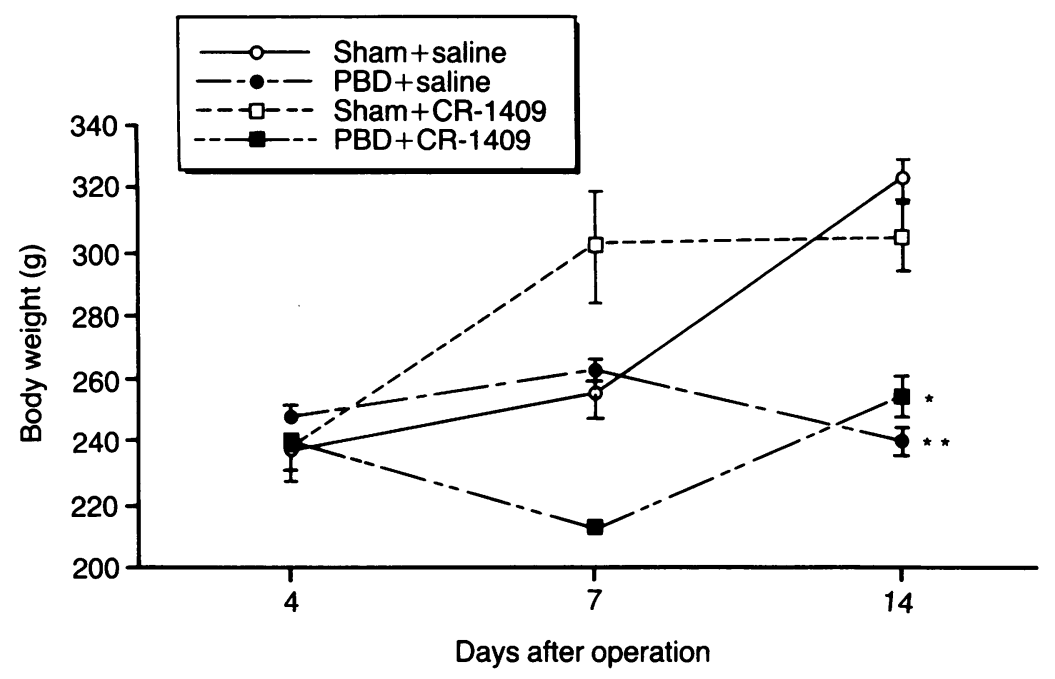

Figure 1: Body weight in rats with pancreatobiliary diversion (PBD) and sham $P B D$. (Values mean $(S E M)$.) Significance v corresponding sham group. ${ }^{\star} p<0.005,{ }^{\star \star} p<0.001$.

and brought to $\mathrm{pH} 9$ by $0.01 \mathrm{~N} \mathrm{NaOH}$ to give a $0 \cdot 4 \%$ solution. Food was reintroduced 12 hours postoperatively. Representatives of each of the four groups were killed at four, seven, and 14 days after operation. Plasma was obtained by direct cardiac puncture for cholecystokinin assay. The

\section{Absolute pancreatic weight}

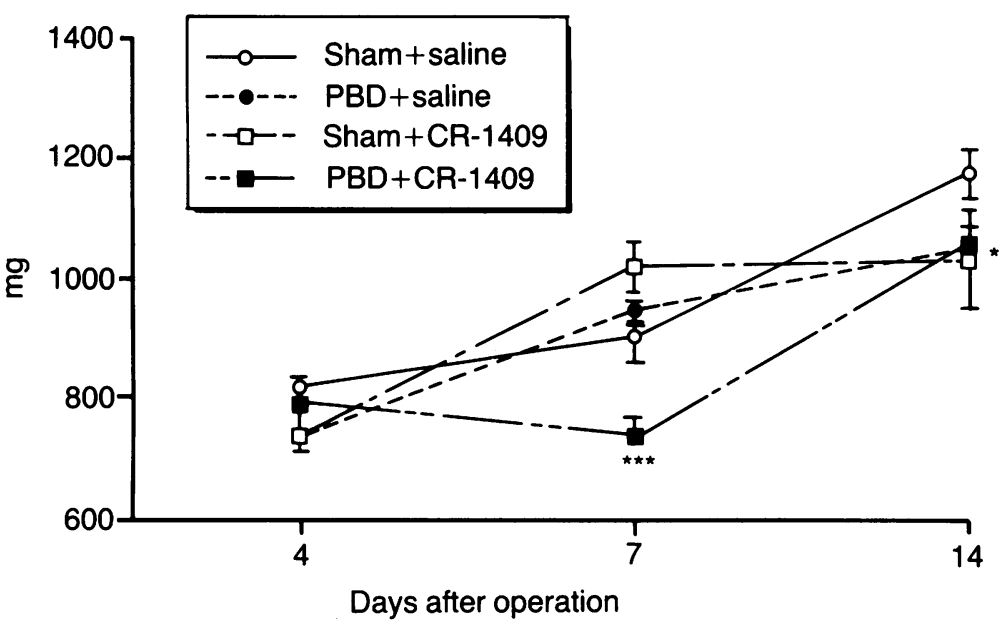

Relative pancreatic weight

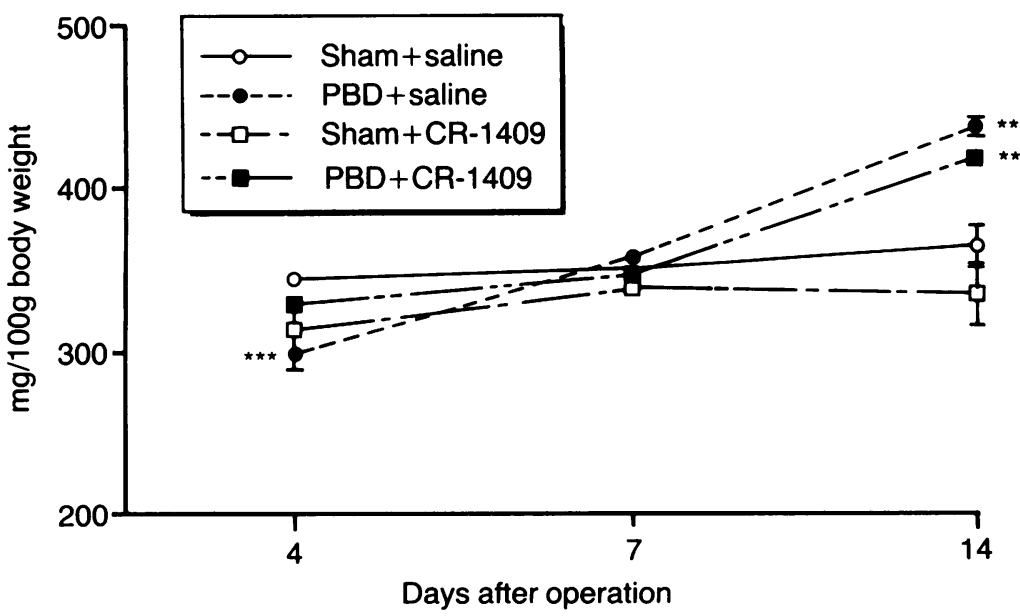

Figure 2: Pancreatic weight (absolute and relative) in rats with pancreatobiliary diversion $(P B D)$ and sham PBD. (Values mean (SEM).) Significance v corresponding sham group. ${ }^{*} p<0 \cdot 05, * * p<0 \cdot 005, * * * p<0 \cdot 001$. pancreas was excised, trimmed free of adherent fat and lymph nodes, and weighed. Small samples were removed for protein and nucleic acid content measurement, bromodeoxyuridine labelling index, and metaphase arrest counting after vincristine injection (see below).

BROMODEOXYURIDINE LABELLING INDEX

The thymidine analogue bromodeoxyuridine is readily and specifically incorporated into DNA during the S-phase of the cell cycle. One hour before sacrifice, rats were given an intraperitoneal injection of 5-bromo- $2^{\prime}$-deoxyuridine ( 50 $\mathrm{mg} / \mathrm{kg}$ body weight). A small sample of the excised pancreas was placed in Carnoy's solution for two to four hours and transferred to $75 \%$ ethanol. Tissue was processed in chloroform, wax embedded, and $4 \mu \mathrm{m}$ sections were cut. Sections were dewaxed and dehydrated in $100 \%$ alcohol. Endogenous peroxidase activity was removed by subsequent immersion in methanol/ hydrogen peroxide $(98 \cdot 4 \% / 1 \cdot 6 \%)$. Dissociation of histones was achieved by using $1 \mathrm{~mol} / 1 \mathrm{HCl}$, which also partially denatured DNA. Each section was treated with a drop of primary antibody (mouse anti-human bromodeoxyuridine, Dako, High Wycombe; 1:20 dilution in phosphate buffered saline). After overnight incubation at $4^{\circ} \mathrm{C}$, the section was incubated with a peroxidase conjugated second antibody (anti-mouse IgG, 1:50 dilution with phosphate buffered saline) for one hour at room temperature. The colour reagent diaminobenzidine plus $\mathrm{H}_{2} \mathrm{O}_{2}$ was used for staining, and each section was counterstained with haematoxylin. The number of S-phase cells in each section was counted and expressed as a percentage of 3500 exocrine pancreatic acinar cells (=labelling index).

\section{METAPHASE ARREST INDEX}

The proliferative status of exocrine pancreatic cells was also assessed by counting the number of cells arrested in metaphase by the stathmokinetic agent vincristine. Rats were killed serially $30,60,90$, and 120 minutes after an intraperitoneal injection of vincristine sulphate $(1 \mathrm{mg} / \mathrm{kg}$ body weight). Pancreatic tissue was placed in formalin solution and was stained with haematoxylin and eosin. The number of arrested metaphase figures was counted per 2000 pancreatic acinar cells. The cell birth rate $\left(K_{b}\right)$ was determined from the slope of the line that was fitted to the data by the method of least squares.

\section{PLASMA CHOLECYSTOKININ ASSAY}

Plasma cholecystokinin peptides were extracted from cardiac blood samples with C18 'SepPak' cartridges (Waters, Harrow, UK,' and eluates were dried by centrifugal evaporation (Savant, Farmingdale NY, USA). Cholecystokinin was measured by a specific radioimmunoassay based on antiserum $A_{2}$, raised by immunising a rabbit with natural porcine cholecystokinin 33 (donated by Professors V Mutt and S R Bloom). Antiserum $\mathrm{A}_{2}(1: 60000)$ was incubated at $4^{\circ} \mathrm{C}$ for three days with standard cholecystokinin 8 or with plasma samples plus cholecystokinin 8 
Total DNA1100 g body weight
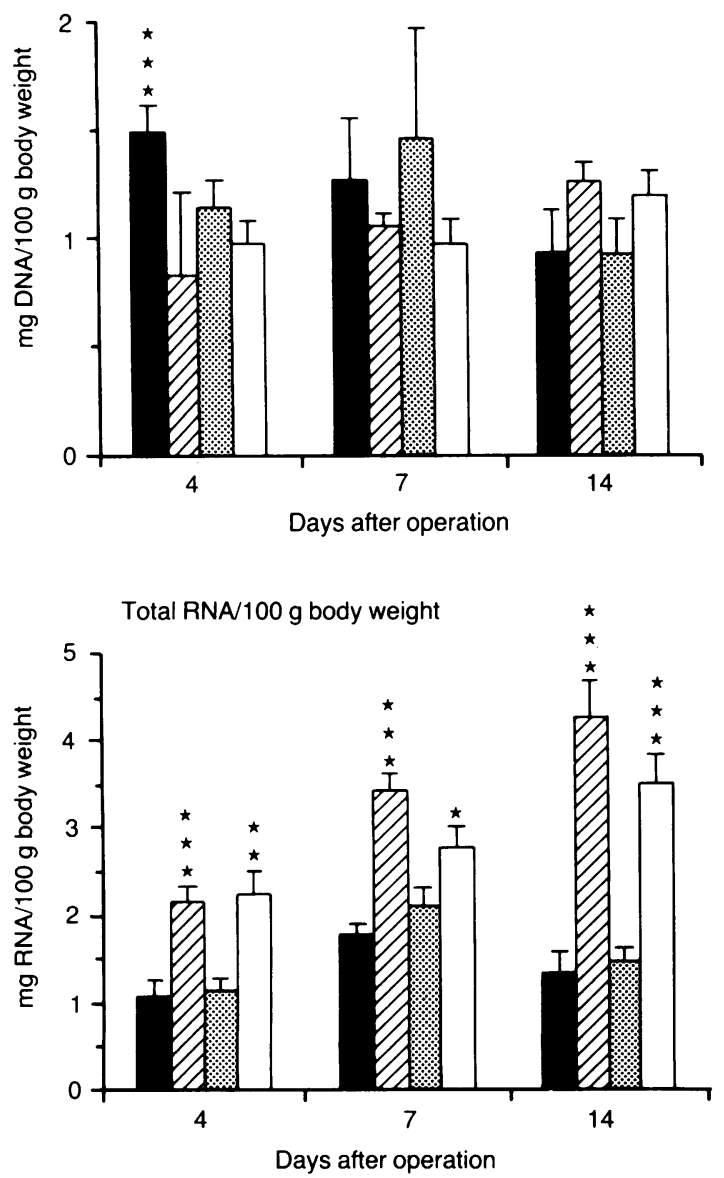

Total protein $/ 100 \mathrm{~g}$ body weight

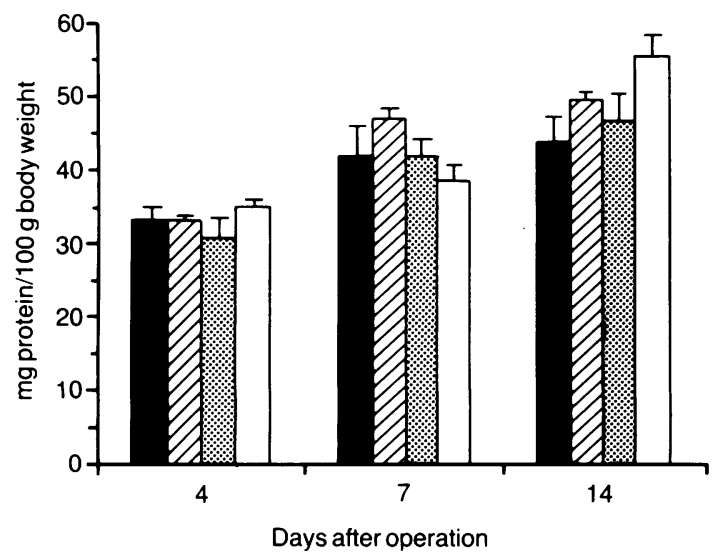

Figure 3: Pancreaticnucleic acid and protein contents per $100 \mathrm{~g}$ body weight. (Values mean $(S E M)$.) Sham =transection (control); $P B D=$ pancreatobiliary diversion. Significance $\mathbf{v}$ corresponding sham group. ${ }^{\star} p<0.05,{ }^{\star \star} p<0 \cdot 002,{ }^{\star \star \star} p<0 \cdot 001$.

tracer labelled with iodine-125 (1000 cpm, Amersham, UK) in $0.05 \mathrm{~mol} / \mathrm{l}$ sodium phosphate buffer $(\mathrm{pH} 7 \cdot 4)$ with $0.25 \%$ gelatin and $0.01 \mathrm{~mol} / \mathrm{l}$ EDTA. Free and bound tracer were separated by the addition of $6 \%$ (weight/volume) charcoal (Norit PN5, BDH, Poole, UK) with $0.6 \%$ (weight/volume) dextran. The concentrations of pure peptides that produced half maximum inhibition of binding of tracer to $A_{2}$ were 2.0 $\mathrm{pmol} / \mathrm{l}$ for cholecystokinin $8,2.4 \mathrm{pmol} / 1$ for cholecystokinin 33 , and $2 \cdot 2 \mathrm{nmol} / 1$ for gastrin 17 . The coefficient of variation within assays was $8 \cdot 2 \%$ and between assays was $12 \cdot 8 \%$. The sensi- tivity of the assay (defined as minimal amount of cholecystokinin 8 that could be distinguished from zero cholecystokinin with $95 \%$ confidence) was $0.2 \mathrm{pmol}$, and the recovery of cholecystokinin 8 and 33 through SepPak and assay procedure was $79 \%$.

BIOCHEMICAL STUDIES

Pancreatic tissue was homogenised in phosphate buffered saline $(136.9 \mathrm{mmol} / \mathrm{l} \mathrm{NaCl}, 2.7 \mathrm{mmol} / \mathrm{l}$ $\mathrm{KCl}, 8.1 \mathrm{mmol} / 1 \quad \mathrm{Na}_{2} \mathrm{HPO}_{4}, \quad 1.5 \mathrm{mmol} / \mathrm{l}$ $\mathrm{KH}_{2} \mathrm{PO}_{4}, 0.9 \mathrm{mmol} / 1 \mathrm{CaCl}_{2}, 0.5 \mathrm{mmol} / 1 \mathrm{MgCl}_{2}$. $6 \mathrm{H}_{2} \mathrm{O}$, adjusted to $\mathrm{pH} 7 \cdot 5$ with $\mathrm{NaOH}$ ), and the concentration of the homogenate was adjusted to $1 \mathrm{mg}$ tissue per ml. Pancreatic contents of DNA and RNA were assayed by the fluorimetric method of Boer ${ }^{8}$ but using an excitation wavelength of $536 \mathrm{~nm}$ and an emission wavelength of $602 \mathrm{~nm}$. ${ }^{9}$ Protein content was determined by the method of Lowry et al. ${ }^{10}$ Since body weight has a profound effect on pancreatic weight, ${ }^{11}{ }^{12}$ protein and nucleic acid contents were expressed as mg per $100 \mathrm{~g}$ body weight to correct for this variable, in line with other workers. ${ }^{13}$

STATISTICAL ANALYSIS

Student's $t$ test for unpaired data was used for the group analysis. Results were given as mean (SEM). The Pearson product moment correlation was used to assess correlations between the results of the bromodeoxyuridine labelling index and metaphase arrest studies.

\section{Results}

MORTALITY AND BODY WEIGHT (Fig 1)

There were nine early deaths from anastomotic leakage (pancreatobiliary diversion 7 , transection 2). There was no significant difference in body weight between the groups at four days. At seven days, rats with pancreatobiliary diversion plus CR-1409 weighed $17 \%$ less than controls (triple transection + saline). By 14 days, pancreatobiliary diversion rats weighed less than shams (by 16-25\%) whether or not they received CR-1409. In sham rats CR-1409 did not affect body weight.

PANCREATIC WEIGHT (Fig 2)

Pancreatic growth occurred with time in every group. Differences in absolute pancreatic weight were generally minor and seemed to reflect differences in body weight. When this variable

Plasma cholecystokinin concentration in rats with pancreatobiliary diversion $(P B D)$ and sham $P B D$. (Values mean $(S E M)$.)

\begin{tabular}{llll}
\hline & \multicolumn{3}{l}{ Cholecystokinin concentration $($ pmolll) } \\
\cline { 2 - 4 } Treatment & At 4 days & At 7 days & At 14 days \\
\hline Sham+saline & $4 \cdot 88(0 \cdot 34)$ & $4 \cdot 53(0 \cdot 81)$ & $3 \cdot 26(0 \cdot 27)$ \\
PBD+saline & $7 \cdot 36(1 \cdot 31)$ & $8 \cdot 64(1 \cdot 17)^{\star}$ & $7 \cdot 71(1 \cdot 82)^{\star}$ \\
Sham+CR1409 & $5 \cdot 42(1 \cdot 15)$ & $3 \cdot 62(0 \cdot 89)$ & $3 \cdot 85(0 \cdot 25)$ \\
PBD+CR1409 & $6 \cdot 62(0 \cdot 87)$ & $8 \cdot 28(1 \cdot 36)^{\star}$ & $7 \cdot 46(1 \cdot 41)^{\star}$
\end{tabular}

Significance $v$ corresponding sham group ${ }^{\star} \mathrm{p}<0.05$. 

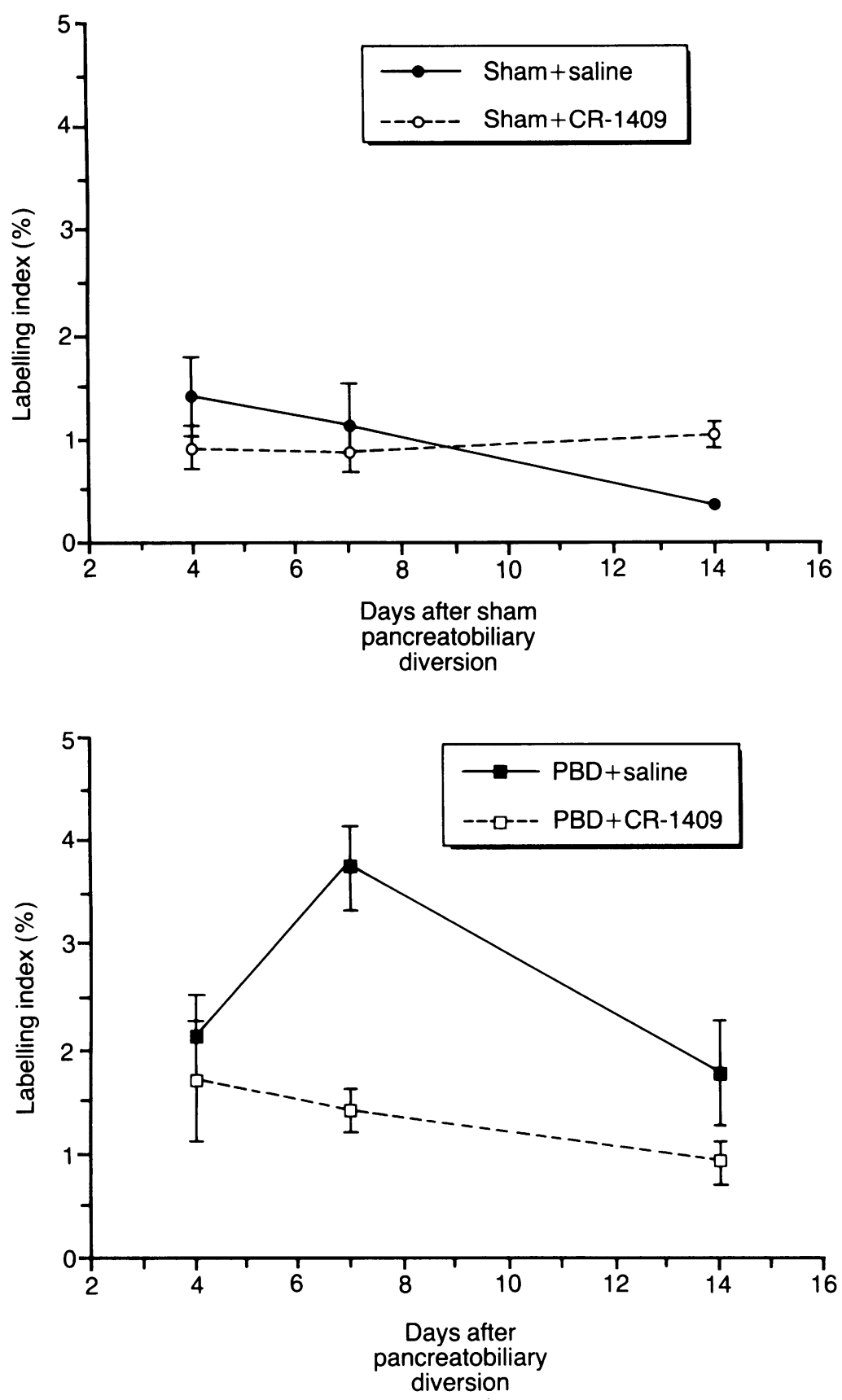

Figure 4: Bromodeoxyuridine labelling index. (Values mean $(S E M)$.) Sham=transection (control); $P B D=$ pancreatobiliary diversion.
NUCLEIC ACID AND PROTEIN CONTENTS (Fig 3)

Pancreatic DNA content steadily increased after pancreatobiliary diversion. Initially, values were lower than in shams but by 14 days there was a (non-significant) $29-34 \%$ increase. Likewise, alterations in protein content were slight, with a trend towards greater values 14 days after pancreatobiliary diversion. By contrast, pancreatobiliary diversion increased RNA content substantially at every time point - by $101 \%$ at four days, $95 \%$ at seven days, and $224 \%$ at 14 days. These increments were partially inhibited by the hormone antagonist CR-1409, being 33\% at seven days $(\mathrm{p}<0.05 v$ pancreatobiliary diversion + saline) and $139 \%$ at 14 days.

BROMODEOXYURIDINE LABELLING INDEX (Fig 4)

Pancreatobiliary diversion sharply increased the bromodeoxyuridine labelling index at seven days $(3.74 v 1.11 \%)$. Thereafter, the proliferative response declined, and at 14 days the difference was much smaller $(1 \cdot 77$ v $0 \cdot 34 \%)$. CR-1409 abolished the effect of pancreatobiliary diversion, so that there was no significant difference from sham values at any time point. CR-1409 had no effect in rats with sham pancreatobiliary diversion.

\section{METAPHASE ARREST INDEX (Fig 5)}

Broadly similar results were obtained by the stathmokinetic technique. Four days after pancreatobiliary diversion, cell birth rate $\left(\mathrm{K}_{\mathrm{b}}\right)$ was already higher than in shams $(0.32 v 0.20 \%)$ and there was a dramatic difference at seven days $(0.60 v 0.09 \%)$ but no residual effect at 14 days. Again, CR-1409 largely abolished the increased birth rate seven days after pancreatobiliary diversion $(0.14 \% v 0.09 \%$ in shams $)$ but had no consistent effect within the sham groups. There was a close correlation between the bromodeoxyuridine labelling and the cell birth rates with a Pearson correlation coefficient of 0.863 (Fig 6).

The potential doubling time of rat pancreatic acinar cells $\left(\mathrm{T}_{\mathrm{pd}}\right)$ was calculated as the reciprocal of the cell birth rate $\left(\mathrm{K}_{\mathrm{b}}\right)$, assuming a rectangular age distribution. $T_{p d}$ in shams was 21 days (four days postoperatively) and 46 days (seven days postoperatively). Pancreatobiliary diversion shortened the doubling time considerably, reducing $T_{\text {pd }}$ to 13 days (at four days) and 6.9 days (at seven days). The cholecystokinin antagonist abrogated this effect, producing a $T_{p d}$ of 30 days (at seven days after pancreatobiliary diversion plus CR-1409). diversion had a clearcut effect: relative pancreatic weight was $20 \%$ greater than shams in saline treated animals and $24 \%$ greater in CR1409 treated animals.

\section{PLASMA CHOLECYSTOKININ (Table)}

Circulating cholecystokinin concentrations were raised four days after pancreatobiliary diversion, but the increase did not attain statistical significance until seven days. Diversion increased plasma cholecystokinin concentrations by $91 \%$ at seven days $(\mathrm{p}<0.05)$ and by $137 \%$ at 14 days $(\mathrm{p}<0 \cdot 05)$. Administration of CR-1409 had no appreciable effect on plasma hormone values.

\section{Discussion}

Our data support a tropic role for cholecystokinin in pancreatic growth after pancreatobiliry diversion, ${ }^{+}$since the operation doubled circulating concentrations of the hormone. There are two possible explanations for this hypercholecystokininaemia. Diversion of pancreatobiliary secretions from the transposed jejunum should suppress the negative feedback mechanism on cholecystokinin secretion, and the jejunal hyperplasia that follows the procedure ${ }^{13}$ might well involve the enteroendocrine cells and lead 


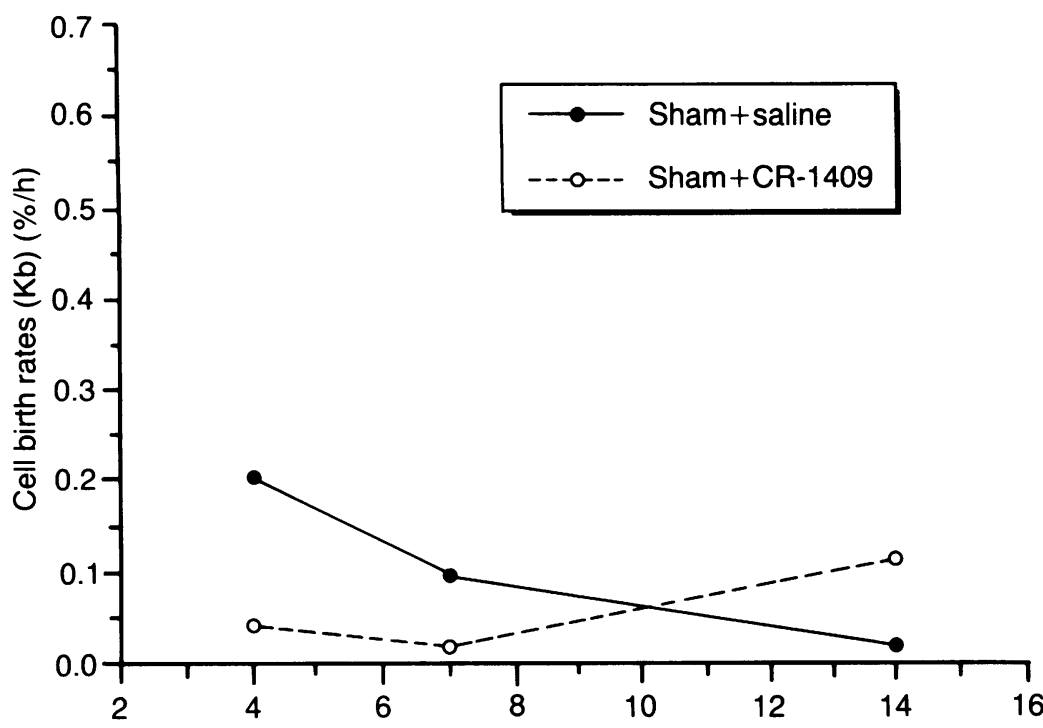

Days after sham pancreatobiliary diversion

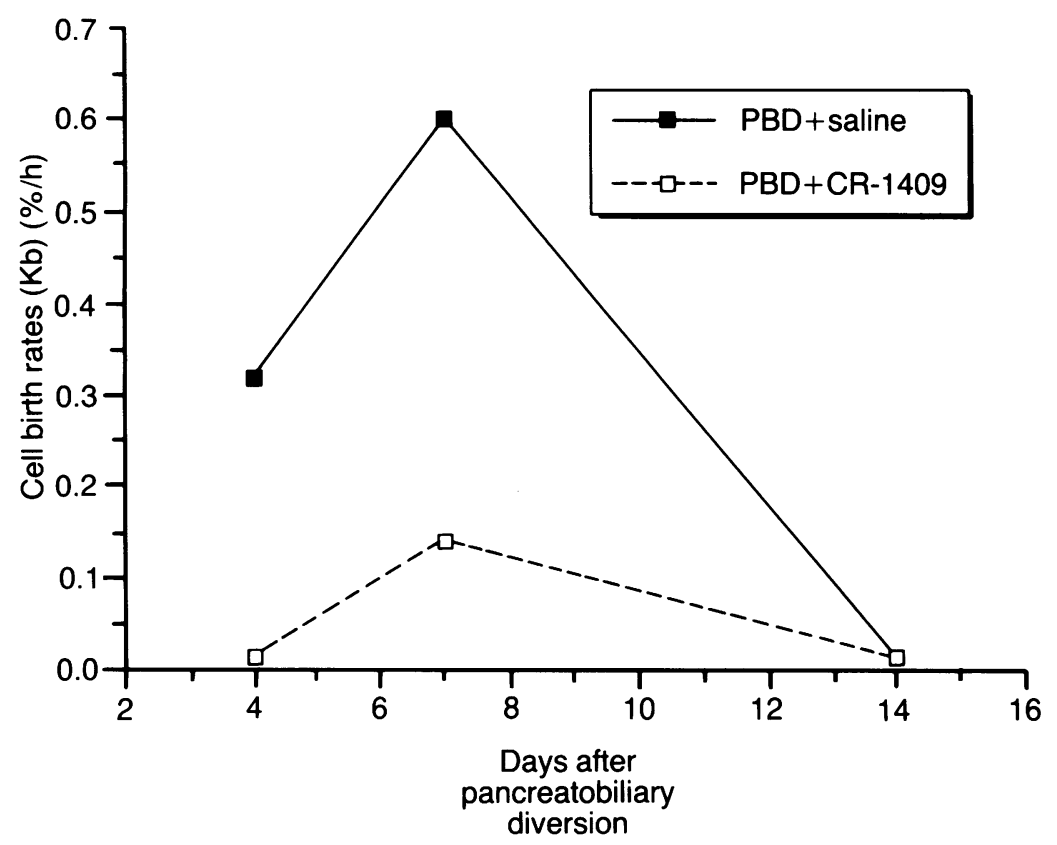

Figure 5: Cell birth rates $(K b)$ per hour, derived from linear regression of metaphase indices. Pancreatic acinar cell doubling time $(T p d)=1 / K b$ :

Thus, $T p d(P B D+$ saline, at 4 days $)=1 / 0 \cdot 0032$ $=312$ hours $=13$ days

Sham $=$ transection (control); $P B D=$ pancreatobiliary diversion tive activity of exocrine pancreatic cells. Moreover, ductular, endocrine, and connective tissue elements will contribute to the RNA, DNA, and protein concentrations in the pancreas. These shortcomings limit the value of looking at indices of pancreatic mass to determine short term changes in exocrine pancreatic growth. We have therefore adapted two direct measurements of cell proliferation to the exocrine pancreas. Bromodeoxyuridine labelling has been widely used in the gastrointestinal mucosa, thyroid, and endocrine pancreas but not previously in the exocrine pancreas. ${ }^{17-19}$ Likewise, the metaphase arrest technique is well established for intestinal mucosa ${ }^{2021}$ and has now been applied to the pancreas. Although baseline numbers of cycling cells are low within pancreatic acini, each technique showed a clearcut burst of proliferative activity seven days after pancreatobiliary diversion with values returning to normal by 14 days. There was an excellent correlation between the bromodeoxyuridine labelling index and cell birth rate but not between these values and nucleic acid or protein content. These techniques are labour intensive, however; they require two to three thousand cells to be counted because of the low level of mitotic activity in the exocrine pancreas.

CR-1409 abolished the hyperplastic response of the pancreas to pancreatobiliary diversion and partially inhibited the hypertrophic response without reducing the high circulating cholecystokinin concentrations. These data confirm that cholecystokinin is indeed involved in the tropic response. The intensity of pancreatic adaptation, however, did not completely accord with circulating cholecystokinin concentrations. Mitotic activity was maximal at seven days and then gradually subsided despite persistent hypercholecystokininaemia. Others have found a similar pattern, which may reflect down regulation of the acinar cell. Nevertheless, pancreatobiliary diversion causes a sustained increase in pancreatic mass ${ }^{46}$ and, in our experience, it enhances azaserine induced carcinogenesis. ${ }^{2}$

We thank the Royal Postgraduate Medical School and the Hammersmith and Queen Charlotte's Special Health Authority for supporting this research, Rotta Research Laboratories (Milan Italy) for kindly providing the CCK antagonist CR-1409 and W K $\mathrm{Man}, \mathrm{S} \mathrm{K} \mathrm{Li}$ for nucleic acid and protein assay.

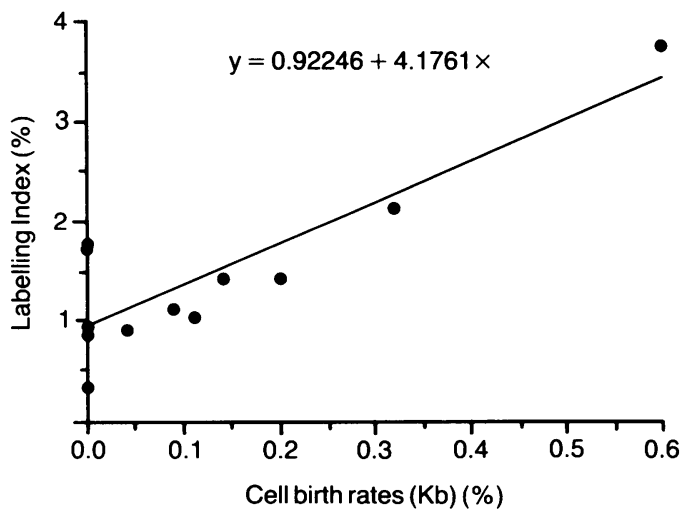

Figure 6: Linear relation between labelling index and cell birth rates $(K b)$ per hour. Pearson correlation coefficient $=$ 0.863 . to increased cholecystokinin production Our finding that the specific cholecystokinin antagonist CR-1409 largely inhibits the proliferation of the pancreatic acinar cells in response to pancreatobiliary diversion underlines its importance as an intermediary. Since relative pancreatic weight increased after diversion despite the cholecystokinin antagonist, however, the hypertrophic response was only partly blocked. CR-1409 is recognised as one of the most potent antagonists of cholecystokinin and is known to prevent the effects of the hormone and its analogue on pancreatic growth. ${ }^{16}$

Assays of nucleic acid and protein content can give only an indirect assessment of the prolifera- 
1 Bristol JB, Williamson RCN. Mechanisms of intestinal adaptation. Pediatr Surg Int 1988; 4: 233-41.

2 Stewart ID, Flaks B, Watanapa P, Davies PW, Williamson RCN. Pancreatobiliary diversion enhances experimental pancreatic carcinogenesis. Br F Cancer 1991; 63: 63-6.

3 Folsch UR, Creatzfeldt W. Adaptation of the pancreas during treatment with enzymes inhibitors in rats and man. Scand $\mathscr{f}$ Gastroenterol 1985; 20 (suppl 112): 54-63.

4 Miazza BM, Widgren S, Chayvialle JA, Ticolet T, Loizeau E. Exocrine pancreatic nodules after longterm pancreaticobiliary diversion in rats. An effect of raised CCK plasm concentrations. Gut 1987; 28 (suppl 1): 269-73.

5 Wright NA, Alison MR. The biology of epithelial cell popula tions. Vol 2. Oxford: Clarendon Press, 1984: 125-49.

6 Stace NH, Palmer TJ, Vaja S, Dowling RH. Longterm pancreaticobiliary diversion stimulates hyperplastic and adenomatous nodules in the rat pancreas: a new model for spontaneous tumour formation. Gut 1987; 28 (suppl 1): 265-8.

7 Eysellein VE, Eberlein GE, Hesse WH, Suger MV, Goebell H, Reeve JR. Cholecystokinin-58 is the major circulating form of cholecystokinin in canine blood. F Biol Chem 1987; 262: $214-7$.

8 Boer GJ. A simplified microassay of DNA and RNA using ethidium bromide. Anal Biochem 1975; 65: 225-31.

9 Le Pecq JB, Paoletti C. A new fluorometric method for RNA and DNA determination. Anal Biochem 1966; 17: 100-7.

10 Lowry OH, Rosebrough NJ, Farr AL. Protein measurement with the Folin phenol reagent. F Biol Chem 1951; 127: $182-6$.

11 Ju JS, Narset ES. Changes in total nitrogen content of some abdominal viscera in fasting and realimentation. $f \mathrm{Nutr}$ 1959; 68: 633-45.

12 Nagy I, Pap A, Varro V. Time-course of changes in pancreatic size and enzyme composition in rats during starvation. Int $\mathcal{f}$ Pancreatol 1989; 5: 35-45.
13 Stock-Damage C, Aprahamian M, Lhoste E, Pousse A, Humbert W, Noriega R, et al. Pancreatic hyperplasia after small bowel resection in the rat: dissociation from endogenous gastrin levels. Digestion 1984; 29: 223-30.

14 Malfertheiner P, Buchler M, Glasbrenner B, Schafmayer A Ditschineit $H$. Adaptative changes of the exocrine pancreas and plasma cholecystokinin release following subtotal gasand plasma cholecystokinin release following subt

15 Miazza BM, Van Hung L, Vaja S, Dowling RH. Effect of pancreatobiliary diversion (PBD) on jejunal and ileal structure and function in the rat. In: Robinson JWL, Dowling $\mathrm{RH}$, Riecken E-O, eds. Mechanisms of intestinal adaptation. Lancaster: MTP Press, 1982: 467-76.

16 Niederau C, Liddle RA, Williams JA, Grendell JH. Pancreatic growth: interaction of exogenous cholecystokinin, a protease inhibitor and a cholecystokinin receptor antagonist in mice. Gut 1987; 28 (suppl 1): 63-9.

17 Imamura $Y$, Sugihara H, Miyake T, Ikeda T, Noriki S Meyoshi $\mathfrak{N}$, et al. Lectin histochemistry in rat thyroid Meyoshi N, et al. Lectin histochemistry in

18 Tatsuta M, Iishi H, Baba M, Taniguchi H. Effect of ornithine decarboxylase inhibitor in tetragastrin treatment of gastric carcinogenesis induced by $\mathrm{N}$-methyl-N'-nitrosoguanidine in Wistar rats. Int $\mathcal{F}$ Cancer 1990; 15: 308-11.

19 Davidson PM, Campbell IL, Oxbrow L, Hutson JM Harrison LC. Pancreatic beta cell proliferation in rabbits demonstrated by bromodeoxy uridine labelling. Pancreas 1989; 4: 594-600.

20 Savage AP, Gornacz GE, Adrian TE, Ghatei MA, Goodlad $\mathrm{RA}$, Wright NA, Bloom SR. Is raised plasma peptide YY after intestinal resection in the rat responsible for the trophic after intestinal resection in the rat

21 Appleton GVN, Bristol JB, Williamson RCN. Proximal enterectomy provides a stronger systemic stimulus to intestinal adaptation than distal enterectomy. Gut 1987; 28 (suppl): 165-8 